\title{
Customer Oriented Marketing Capabilities and Firm Performance Mediated by New Product Development Capabilities and Moderated by Environmental Turbulence
}

\section{Harram A*and Fozia M}

Management Sciences Department, Army Public College of Management and Sciences (APCOMS), (Affiliated with UET, Taxila), Rawalpindi, Pakistan

\begin{abstract}
This study is carried out to analyze the impact of customer oriented marketing capabilities on firm performance mediated by new product development capabilities. The manufacturing sector of Pakistan is selected for this study and data was collected from managers who are involved in marketing and product development decisions. The sample size for this research was 100 . The results were analyzed using statistical tools. Reliability of data is measured through Cronbach's Alpha, correlation, regression and mediating regression analysis was also assessed. The results were positive and all of the hypothesized relations were supported. This study is significant for the top level management of different organizations to improve their overall performance through marketing and new product development capabilities in order to retain their customers and to cope with ever dynamic market.
\end{abstract}

Keywords: Customer oriented marketing capabilities; New Product development capabilities; Market turbulence; Firm performance

\section{Introduction}

How Customer oriented marketing abilities impact general business performance is a focal goal of this marketing exploration.

In this $21^{\text {st }}$ century, with a specific end goal to get focused edge over competitors and to stay in the business sector, it is vital for each organization to wind up mindful of the critical part that the customer plays. As today, the business sector is described by various items, a mixture of customers. In such a circumstance, promoting has turn into a need. Today the expression "advertising endeavors" is considerably not the same as that utilized as a part of the past. Marketing is more refined these days. Power of rivalry, fast globalization, changing data innovation, and changing purchaser profile (socio-demographic) has an in number impact on advertising. In this way, advertising directors are moving their center from offering to making something that is required. Beginning from creation to offering and overhauling, buyer center is given the need. Organizations need to profit to stay suitable. Despite the fact that it may appear to be logical, here and there a customer arranged system brings about a larger number of benefits than a deals situated methodology. Subsequently, the essential objective of marketing and customer situated organizations is to get long haul gainfulness.

It is difficult to begin this paper without describing customer oriented marketing capabilities (COMC) and such affiliations. At first, a customer oriented association is an association that spotlights on customer enhancements in arranging its advancing strategies and on passing on preferred regard over its objective customers and COMC insinuates an affiliation's ability to send and appropriate publicizing resources for performing conclusive focuses of purchaser dependability and brand esteem. Customer oriented capabilities are socially complicated, and suggested when stood out from other firm capacities, and hence they are found to be more huge for the firm. Along these lines, COMC effects firms' genuine and future execution through (1) the ability to get new customers for current offerings (positive casual trade of existing customers leads new customers to have a go at existing offerings) (2) the ability to bolster cross-buying from current customers (brand care and positive brand associations) [1-3].

After an apparently unending measure of time, administrators attempt to upgrade financial performance and firm regard by advancing exercises, for instance, new product development (NPD) and special motivations. New product development (NPD) has been depicted as a higher-demand capacity that incorporates different progressive limits and abilities to make a thing which satisfy customer needs. The advancing of new things has been able to be dynamically basic to the benefit of organizations. The vital clarification behind frustration on occasion is poor understanding of customer needs. A couple of specialists $[4,5]$ have recommended that customer learning can enhance the way of a thing or organization. The journey for information about purchaser's latest examples is essential for NPD accomplishment. Firms furthermore should have adequate levels of testing resources and aptitudes to sort out their activities. Firms without these assets experience issues dispatching new items and in this way are liable to come up short in the business. Accordingly, the more prominent a company's marketing ability in including customers amid product improvement, the higher the association's general performance. This study relates to the method for dependence among these three techniques, building up the work by Srivastava [6]. The study evaluates if this can be outlined tentatively. The significance of the study gets from three segments: (a) not very numerous studies have perceived that marketing part adds to better execution of general authoritative procedures; (b) there is a need to see better how promoting abilities impact procedures, for example, NPD that have been customarily considered as being past the obligation of the advertising capacity and (c) there is a need to all the while connect each of the three hierarchical procedures to general firm execution and estimation of firms.

The rest of this research is organized as follows. The first section discusses general characteristics of marketing capabilities and new

${ }^{*}$ Corresponding author: Harram Aneeqa, BBA Student, Management Sciences Department, Army Public College of Management and Sciences (APCOMS), (Affiliated with UET, Taxila), Rawalpindi, Pakistan, Tel: + +92 51 5827830; E-mail: harram_786@hotmail.com

Received July 23, 2015; Accepted August 26, 2015; Published September 01, 2015

Citation: Harram A, Fozia M (2015) Customer Oriented Marketing Capabilities and Firm Performance Mediated by New Product Development Capabilities and Moderated by Environmental Turbulence. Int J Econ Manag Sci 4: 282. doi:10.4172/21626359.1000282

Copyright: ( 2015 Harram A, et al. This is an open-access article distributed unde the terms of the Creative Commons Attribution License, which permits unrestricted use, distribution, and reproduction in any medium, provided the original author and source are credited. 
product development process; it is followed by the introduction of the research model. The next section specifies the hypotheses. This section is followed by a discussion of the data and variables and the presentation of the model. The final sections present the empirical results and discuss the main conclusions.

\section{Literature Review}

To compose the writing, I ground my review on the asset based perspective of the associations and their capacity hypotheses. Asset based speculations see a firm as a heap of substantial and immaterial resources, for example, human and different assets, that can be utilized to actualize quality making techniques to enhance their proficiency and viability $[7,8]$.

\section{Determinants of firms performance}

In the business strategy writing there are two noteworthy surges of examination on the determinants of firm performance. One is based essentially upon a financial convention, accentuating the significance of outer business figures deciding firm achievement. The other line of examination expands on the behavioral and sociological standard and sees authoritative variables and their fit with the earth as the real determinants of achievement. Inside of this school of thought, minimal direct consideration is given to the company's focused position. Additionally, financial matters generally have slighted elements inner to the firm. Hypothesis or exact confirmation of linkages to execution flourishes inside of every standard. Be that as it may, shockingly little has been done to incorporate the two and assess the relative impact of each on firm gains. Outstanding exemptions are late works by Grinyer and McKiernan [9] who examined andior assessed a predetermined number of unforeseen connections in the middle of monetary and authoritative variables. No work has been finished, not withstanding, to evaluate the relative significance of these two arrangements of illustrative variables.

\section{Market turbulence}

Market turbulence- changes in the organization of customers and their inclinations is a subset of the natural turbulence build [10]. Their matrices turbulence is very much alike to "heterogeneity," which portrays as the "change in differences of generation systems and promoting strategies needed to indulge customers' requirements." Because market turbulence infers changing procedures despite changing client needs, I expect a negative relationship with execution. Dess and Beard [11] portray the ecological turbulence and dynamism as changes that are eccentric and hard to get ready.

\section{New product development capabilities}

In these exceedingly focused markets an organization's NPD assets and capacities drive the best upper hand. The quest for data about customer's present and inactive needs is crucial for NPD achievement. While the development and promoting of items has turn out to be imperative to the benefit and development of firms, however the disappointment rate of recently portrayed items still keeps on staying high. In this way, the essential explanation behind disappointment which has been distinguished is poor comprehension of customer needs and requests. As indicated by Kohli [10] thought to data about customer necessities ought to be considered adjacent to the essential arrangement of qualities and convictions that are prone to support such a customer center. Firms which have abnormal amounts of customer introduction attempt to gather more client data from different perspectives. A lot of this data will probably be accumulated through customer contribution in new product development process. Customers are prone to feel higher dangers when items are more confounded on the grounds that the trouble in comprehension the item prompts uncertainty, expanding the methodology that an obscure negative result may happen [12]. Subsequently, organizations must consider data on customer conclusion of item multifaceted nature and join this data into their item procedures to decrease the customers judgment. This effort will result in greater customer assistance in the NPD process.

\section{Customer oriented marketing capabilities}

The part of marketing abilities in clarifying firms' performance has gotten huge thought all through the historical backdrop of the promoting on the planet. A few crevices exist in the advertising writing in regards to firm procedures, promoting capacities, and execution. Advertising capacity is one of the capacities that enormously impact advancement execution of the association. Two reliant advertising abilities have been distinguished: Capabilities concerning individual procedures, for example, item improvement and administration, evaluating, offering, promoting correspondences, and channel administration [13], and capacities related with the procedures of marketing method advancement and performance [14]. Interestingly, directors frequently consider the procedures of advertising as being more basic than item advancement [15]. Besides, promoting abilities may rot over the long run if not ceaselessly enhanced through authoritative learning [16]. A few studies allude to Customer oriented marketing capabilities as the specialty of utilizing marketing assets as a part of making customer esteem [17,18]. Different studies disintegrate these capabilities into brand administration and customer relationship administration abilities. Earlier research recognizes that promoting capacities produce more noteworthy change in firm execution when joined with other integral assets and abilities, for example, business sector based information resources $[19,20]$ and innovation abilities [21,22]. Hence, Marketing abilities empower firms to make obstructions to securing, along these lines driving predominant firm performance. On the other hand, various abilities of every sort have gotten consideration in the late advertising writing.

\section{Specialized marketing capabilities}

Specific marketing capabilities concern the particular practically based procedures utilized inside of the association to change assets. While specific capabilities may include arranging with different capabilities and draw on inputs from outside of the promoting range, the center of these abilities dwells in the advertising capacity. Particular marketing capabilities have subsequently ordinarily been seen as including the strategic marketing project related procedures regularly expected to execute promoting system. The writing proposes that specific advertising abilities are based around the traditional "marketing blend" of exercises concerned with item, estimating, correspondences, and appropriation [23].

\section{Product management}

This ability concerns the procedure of adjusting, keeping up, and conveying item and administration offerings to fulfill customer needs [24]. Producing and conveying profitable and engaging item/benefit offerings obliges very much created hierarchical schedules for assessing item/benefit execution [25] and adjusting existing item/administration offerings to match changing customers prerequisites and focused goals [26]. 


\section{Pricing management}

Price is a key segment of the quality conveyed to customers through business offerings [27,28]. Value sways both the expense and saw quality sides of the customer esteem "mathematical statement," and the capacity to oversee evaluating adequately is in this manner an essential promoting ability. Firms use this information to create proper estimating procedures, to rapidly and adequately execute and convey evaluating changes when obliged [29].

\section{Channel administration}

Channel individuals perform huge worth added exercises in connection to end-customers, customers in numerous commercial centers, commonly including somewhere around $15 \%$ and $40 \%$ of aggregate quality [30]. The capacity to productively and adequately oversee associations with channel individuals has accordingly long been perceived as a vital marketing ability [31]. This has been connected with exercises, for example, supporting channel part endeavors and creating and keeping up commonly helpful connections [32].

\section{Selling}

Selling abilities may be seen as including two related components. The primary concerns the abilities of faculty occupied with offering exercises. These identify with the essential way of the offering assignment in regards to dissecting customer needs, giving data, and working with present and potential customers to guarantee need fulfillment and improvement and administration of associations with customers. The second component concerns the frameworks and structures needed to guarantee effective and powerful administration of the business power [33]. Both components of an selling capacity have been joined with firms' capacity to convey customer esteem and accomplish prevalent execution.

\section{Brand management capability}

This concerns the frameworks and procedures used to create, develop, keep up, and influence a firms image resources. As being what is indicated, brand administration includes drawing together various specific promoting abilities, for example, statistical surveying, item administration, valuing, and advertising correspondences capacities for particular brands [34]. It likewise consolidates these with inputs from RandD (development pipeline arranging), bookkeeping (deals volume and acknowledged valuing information), generation (item quality information and timetable arranging), and operations (conveyance lead-time execution observing) to create and execute brand level strategies for success [35].

\section{CRM capability}

This concerns the company's capacity to recognize alluring customers and prospects, start and keep up associations with these appealing customers, and influences these connections into customer level benefits [36]. A firm CRM ability in this way embodies schedules that take into consideration the co-appointment of various lower-level inputs, for example, deals reporting frameworks, statistical surveying reports, client database investigations, client administration experience mapping, and so forth.

\section{New product development capability}

This relates to the company's capacity to make important new product offerings for its objective markets. This regularly includes getting business and specialized learning from inside and outside the firm and coordinating this information to make new experiences with respect to product making offering potential outcomes [37], and finding, gaining, and sending the integral assets needed to make, create, and convey the chose worth offering.

\section{Dynamic marketing capabilities}

Dynamic abilities concern the firms capacity to take part in business based learning and utilize the subsequent understanding to upgrade its capacities in ways that mirror the firms dynamic business environment. Dynamic abilities hypothesis places that so as to convey maintained upper hand in element situations, the firms assets and capacities should be consistently changed, created, and improved. In view of the dynamic way of businesses, assets and abilities that neglect to develop to fit the changing requests of the firm's business sectors make hierarchical rigidities [38]. These rigidities forestall adjustment to natural change and regularly prompt lower quality results. In this manner, Dynamic Capabilities hypothesis recommends that it is vital that organizations create forms for asset reconfiguration and ability upgrade directing interests in new assets and capacities, choosing which to discharge, and which to enhance and how to do as such in Figure 1.

\section{Hypothesis}

H1: Customer oriented marketing capabilities are positively associated with a firm's performance

H2: Firm's COMC are positively associated to new product development capabilities

H3: New product development capability has direct relation with firm financial performance

H4: The interaction between COMC and New product development capability is positively associated with firm's performance

H5: Market turbulence moderates the relationship between new product development capability and firm performance.

\section{Research Methodology}

\section{Sampling method}

A sampling frame of Pakistani firms was developed for four big cities. Using a Judgmental sampling procedure four industries were selected. The key informants were defined as managers of marketing and sales function. Then my research process was initiated with finding a contact person in each firm. This person has given complete information about my survey and then questionnaires were distributed with the help of contacted person to each department in firms. Questionnaire was used as data collection instruments. The main section of the questionnaire was intended for gathering demographic information, such as age, gender, tenure and the salaries. The next section includes information regarding firms capabilities. Then total of the entire questionnaire is calculated (Appendix).

\section{Research design}

It is a hypothesis testing study where the role of different dimensions in the formation of customer oriented marketing capabilities was studied in Pakistani context along with the effect of new product development process on firm's performance. The data was collected through questionnaires from people of organizations working in different industries and later used for regression and correlation analysis by using SPSS (statistical package for social sciences). 


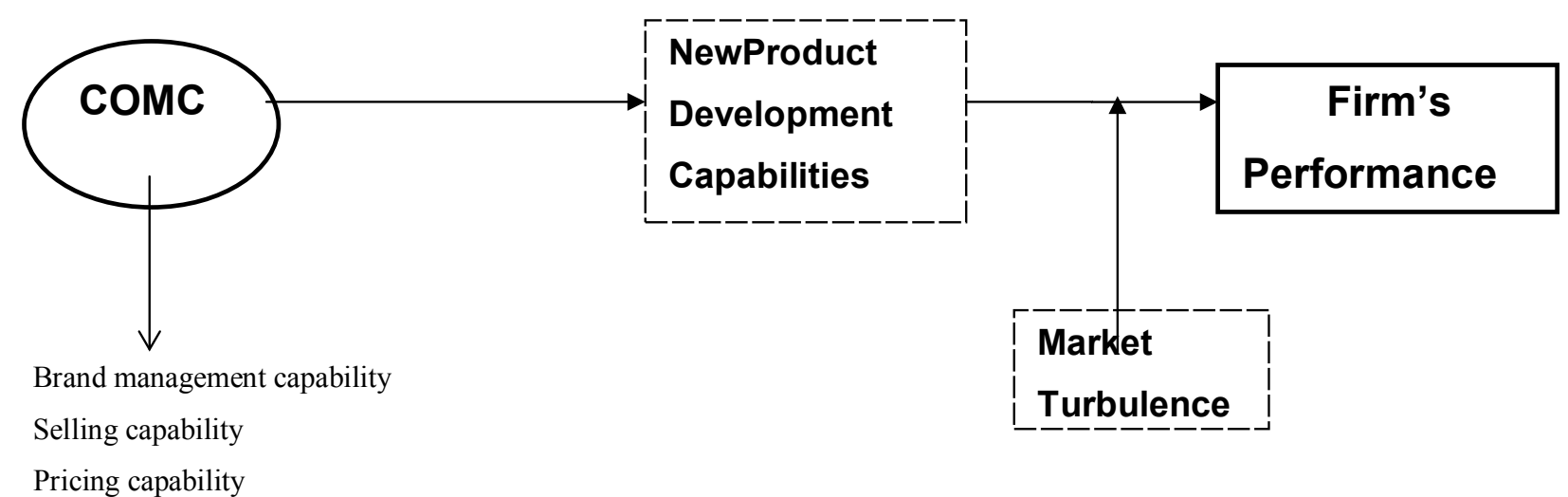

Figure 1: Research model.

\section{Sample selection}

A sample size that is greater than 30 and smaller than 500 is very much appropriate for many studies [39]. In this study a sample of 100 was drawn from the population. All of the respondents were managers of different departments and they are working in their organizations for definite time period.

\section{Measurement scale}

The constructs is measured through various items. All items are measured using five point likert scale starting from 1 . Strongly disagree 2. Disagree 3. Neutral 4. Agree 5. Strongly agree for all the variables. The questionnaires were adapted from different articles and for each variable were appropriately chosen. The total questions were 37 , where 6 questions were of customer oriented marketing capabilities, 7 were of brand management capabilities, 4 of pricing capability, 5 of selling capability, 6 of new product development capability, 4 of market turbulence and 5 of firm performance.

\section{Data collection procedures}

A total of 100 questionnaires were administered personally to the managers of different industrial sectors. Their demographics, such as age, gender, education, designation, years with organization were asked as well.

\section{Demographics information}

Demographics illustrates (Table 1) that male respondents were larger than female respondents with percentage of 68. More results were witnessed by the managers of age group 26-30. Rests of age groups have very low percentage. 51 percent of Managers had education level of Master, 36\% had Bachelor's degree. Designations were mostly of department managers of different organizations from which $27 \%$ were Marketing manager and $25 \%$ of marketing directors. Income level of majority respondents was between $31,000-40,000$. Tenure of $38 \%$ managers was 1-5 years with current organization. Different industries were selected for this research and from above demographic results it indicates that $60 \%$ of managers were of Home appliance industry of Pakistan.

\section{Data analysis techniques}

- Descriptive statistics

- Correlation

- Regression

Statistical software: SPSS (statistical package for social sciences) was used for the analysis of the data collected for this study.

\section{Reliability and validity}

A pilot test would be conducted to check the reliability and validity of the scale.

\section{Data analysis}

Once the data was collected, it was punched into SPSS software. The data was added according to the responses provided by the interviewees for each question of each variable. The second thing that needed to be done was form means/averages of all the variables.

\section{Reliability}

Reliability of variables is checked through the Cronbach Alpha Test (a). In this test, I added all the items (questions) of my variables separately instead of their means. The reliability should lie above from 0.7 and below 1.00 .

Table 2 indicates Cronchbach alpha for uniqueness of scale items. Customer oriented marketing capabilities were measured by 15 items proposed by Cruz-Ros and Gonzalez-Cruz. Sub variables of COMC include brand management capability, pricing capability and selling capability. New product development capability has alpha value 0.763 which is measured by 6 items proposed by Murray and Kotabe. Market turbulence shows alpha value of 0.674 with 2 items proposed by Narver [40,41]. And Firm's performance was measured by 5 scale items proposed by Murray and Kotabe. Overall reliability of all question items is very good. 
Citation: Harram A, Fozia M (2015) Customer Oriented Marketing Capabilities and Firm Performance Mediated by New Product Development Capabilities and Moderated by Environmental Turbulence. Int J Econ Manag Sci 4: 282. doi:10.4172/21626359.1000282

Page 5 of 8

\begin{tabular}{|c|c|c|}
\hline Demographics & Frequencies & Percentage \\
\hline \multicolumn{3}{|l|}{ Age } \\
\hline $26-30$ & 58 & 58 \\
\hline $31-35$ & 26 & 26 \\
\hline $36-40$ & 6 & 6 \\
\hline $41-45$ & 5 & 5 \\
\hline $46-50$ & 2 & 2 \\
\hline Above 50 & 3 & 3 \\
\hline \multicolumn{3}{|l|}{ Gender } \\
\hline Male & 68 & 68 \\
\hline Female & 32 & 32 \\
\hline \multicolumn{3}{|l|}{ Education } \\
\hline Bachelors & 36 & 36 \\
\hline Masters & 51 & 51 \\
\hline MS & 2 & 2 \\
\hline Phd & 2 & 2 \\
\hline 5 & 9 & 9 \\
\hline \multicolumn{3}{|l|}{ Designation } \\
\hline Managing Director & 8 & 8 \\
\hline Sales Director & 6 & 6 \\
\hline Sales manager & 29 & 29 \\
\hline Marketing Director & 25 & 25 \\
\hline Marketing manager & 27 & 27 \\
\hline $\mathrm{R}$ and $\mathrm{D}$ manager & 2 & 2 \\
\hline Production manager & 3 & 3 \\
\hline \multicolumn{3}{|l|}{ Income } \\
\hline Less 30,000 & 8 & 8 \\
\hline $31,000-40,000$ & 33 & 33 \\
\hline $41,000-50,000$ & 22 & 22 \\
\hline $51000-60,000$ & 21 & 21 \\
\hline Above 61,000 & 16 & 16 \\
\hline \multicolumn{3}{|l|}{ Tenure } \\
\hline Less than a year & 8 & 8 \\
\hline 5-Jan & 38 & 38 \\
\hline 10-Jun & 33 & 33 \\
\hline 15-Nov & 16 & 16 \\
\hline $16-20$ & 5 & 5 \\
\hline Total & 100 & 100 \\
\hline \multicolumn{3}{|l|}{ Industry } \\
\hline Home appliances & 60 & 60 \\
\hline $\begin{array}{l}\text { Electronics and } \\
\text { Electrical }\end{array}$ & 2 & 2 \\
\hline FMCG & 23 & 23 \\
\hline Others & 15 & 15 \\
\hline
\end{tabular}

Table 1: Respondents of Study.

\section{Independent variables}

Customer oriented marketing capability: A 15 item set of questions was adapted from the research papers published by Cruz-Ros and Gonzalez-Cruz, Vorhies and Orr [5], Mrray and Kotabe, Morgan and Vorhies [18].

New product development capability: Six question items for New Product Development Capability were derived from the paper of Murray and Kotabe.

Market turbulence: 2 question items were adapted from research paper of Narver [41].

\begin{tabular}{|c|c|c|}
\hline & Cronbach's alpha & Number of items (N) \\
\hline COMC (BMC, PC, SC) & 0.859 & 15 \\
\hline NPDC & 0.763 & 6 \\
\hline MT & 0.674 & 2 \\
\hline FP & 0.814 & 5 \\
\hline Total & & 37 \\
\hline
\end{tabular}

Table 2: Reliability statistics.

\begin{tabular}{|l|c|c|c|c|c|}
\hline \multicolumn{7}{|l|}{ Descriptive Statistics } \\
\hline & N & Minimum & Maximum & Mean & Std. Deviation \\
\hline COMC & 100 & 2.40 & 4.80 & 4.0047 & .55465 \\
\hline NPDC & 100 & 2.50 & 5.00 & 3.9417 & .58429 \\
\hline MT & 100 & 2.75 & 4.50 & 3.8675 & .50684 \\
\hline FP & 100 & 2.60 & 5.00 & 4.2240 & .60254 \\
\hline Valid N (listwise) & 100 & & & & \\
\hline
\end{tabular}

Table 3: Descriptive statistics.

\section{Dependent variable}

Firm performance: Firm performance was also adapted from a 5 item question set from the paper of Murray and Kotabe.

Descriptive statistics: Table 3 provides some very useful descriptive statistics, including the mean, standard deviation and confidence intervals for the dependent variables FP and its impact on the independent variables i.e. COMC, NPDC and MT.

Correlation: Five hypotheses were addressed in this study in which all of the hypotheses tested out to be positive. This was tested by correlating three independent variables (COMC, BMC, SC, PC, NPDC, MT) with dependent variable (FP). As noted in Table 4, all the relations came out to be positive ( $\gamma$ for FP was $53.4 \%, \gamma$ COMC was $53.4 \%$ and $\gamma$ NPDC was $58.1 \%$ and MT was $44.7 \%$, along with significance level $\mathrm{p}=0.000$ at all variables)

Regression: The regression is the intensity of relationships between the variables to perform regression; I added the means in the regression computation. Regression was run to test the hypothesis through the significant values of ANOVA and coefficient models. As author was finding the relationship of one dependent variable with three independent variables regression was run four times.

The values of significant level of ANOVA and coefficient model had to be $\mathrm{p}<0.05$ to accept the hypothesis for each of the dependent and independent variables. Value was 0.000 ; lying in the given range therefore my hypotheses were approved.

Table 5 represents the estimates of the regression coefficients and values of variance ( $t$ ) etc. As the values of ' $t$ ' are above 2 , and there is no negative sign, it shows that my hypothesis is accepted (Tables 6-8).

\section{Results}

All of my hypothesis stands true as the significance level lies within the desired limit, meaning that Customer oriented marketing capabilities have a actual impact on firms performance. A customer introduction has long been pushed as a business reasoning that prompts prevalent execution and firm performance [41]. Thus, the customer orientation build has been experiencing reasonable level headed discussion and exact approval $[42,43]$. For the particular purposes of this paper, customer orientation is viewed as a vital introduction that mirrors the company's capacity to make and convey predominant client esteem through the preparing of business sector knowledge. 
Citation: Harram A, Fozia M (2015) Customer Oriented Marketing Capabilities and Firm Performance Mediated by New Product Development Capabilities and Moderated by Environmental Turbulence. Int J Econ Manag Sci 4: 282. doi:10.4172/21626359.1000282

Page 6 of 8

\begin{tabular}{|c|c|c|c|c|c|}
\hline \multicolumn{6}{|c|}{ Correlations } \\
\hline & & FP & COMC & NPDC & MT \\
\hline \multirow[t]{3}{*}{$\mathrm{FP}$} & Pearson Correlation & 1 & $0.534^{* *}$ & $0.581^{* *}$ & $0.447^{* *}$ \\
\hline & Sig. (2-tailed) & & 0.000 & 0.000 & 0.000 \\
\hline & $\mathrm{N}$ & 100 & 100 & 100 & 100 \\
\hline \multirow[t]{3}{*}{ COMC } & Pearson Correlation & $0.534^{* *}$ & 1 & $0.481^{* *}$ & $0.378^{* *}$ \\
\hline & Sig. (2-tailed) & 0.000 & & 0.000 & 0.000 \\
\hline & $\mathrm{N}$ & 100 & 100 & 100 & 100 \\
\hline \multirow[t]{3}{*}{ NPDC } & Pearson Correlation & $0.581^{* *}$ & $0.481^{* *}$ & 1 & $0.370^{\star *}$ \\
\hline & Sig. (2-tailed) & 0.000 & .000 & & 0.000 \\
\hline & $\mathrm{N}$ & 100 & 100 & 100 & 100 \\
\hline \multirow[t]{3}{*}{ MT } & Pearson Correlation & $0.447^{* *}$ & $0.378^{* *}$ & $0.370^{* *}$ & 1 \\
\hline & Sig. (2-tailed) & 0.000 & 0.000 & 0.000 & \\
\hline & $\mathrm{N}$ & 100 & 100 & 100 & 100 \\
\hline
\end{tabular}

${ }^{* *}$ Correlation is significant at the 0.01 level (2-tailed)

Table 4: Correlation analysis.

\begin{tabular}{|c|c|c|c|c|c|c|}
\hline \multicolumn{7}{|c|}{ Coefficients $^{a}$} \\
\hline \multicolumn{2}{|c|}{ Model } & \multicolumn{2}{|c|}{$\begin{array}{l}\text { Unstandardized } \\
\text { Coefficients }\end{array}$} & \multirow{2}{*}{$\begin{array}{c}\text { Standardized } \\
\text { Coefficients } \\
\text { Beta }\end{array}$} & \multirow[t]{2}{*}{$\mathbf{t}$} & \multirow[t]{2}{*}{ Sig. } \\
\hline & & $B$ & Std. Error & & & \\
\hline \multirow[t]{4}{*}{1} & (Constant) & 0.565 & 0.425 & & 1.329 & 0.187 \\
\hline & COMC & 0.302 & 0.096 & 0.278 & 3.132 & 0.002 \\
\hline & NPDC & 0.383 & 0.091 & 0.371 & 4.203 & 0.000 \\
\hline & MT & 0.243 & 0.099 & 0.205 & 2.449 & 0.016 \\
\hline
\end{tabular}

aDependent variable: FP

Table 5: Regression analysis; effect of independent variables on firm's performance.

\begin{tabular}{|l|c|c|c|c|}
\hline \multicolumn{4}{|l|}{ Model Summary } \\
\hline Model & $\mathbf{R}$ & R Square & Adjusted R Square & Std. Error of the Estimate \\
\hline 1 & $0.675^{\mathrm{a}}$ & 0.455 & 0.438 & 0.45158 \\
\hline
\end{tabular}

aPredictors: (Constant), MT, NPDC, COMC

Table 6: Regression analysis (model summary).

\begin{tabular}{|c|c|c|c|c|c|c|}
\hline \multicolumn{7}{|c|}{ ANOVA $^{b}$} \\
\hline \multicolumn{2}{|c|}{ Model } & \multirow{2}{*}{$\begin{array}{c}\begin{array}{c}\text { Sum of } \\
\text { Squares }\end{array} \\
16.366\end{array}$} & \multirow{2}{*}{$\begin{array}{l}\text { Df } \\
3\end{array}$} & \multirow{2}{*}{$\begin{array}{c}\text { Mean Square } \\
5.455\end{array}$} & \multirow{2}{*}{$\begin{array}{c}\mathbf{F} \\
26.752\end{array}$} & \multirow{2}{*}{$\begin{array}{l}\text { Sig. } \\
0.000^{a}\end{array}$} \\
\hline 1 & Regression & & & & & \\
\hline & Residual & 19.576 & 96 & 0.204 & & \\
\hline & Total & 35.942 & 99 & & & \\
\hline
\end{tabular}

aPredictors: (Constant), MT, NPDC, COMC

bDependent Variable: FP

Table 7: Regression analysis; variance caused by Market turbulence on firms performance (ANOVA).

\begin{tabular}{|l|c|c|c|c|c|}
\hline Direct Effect & R square & Beta & $\mathbf{t}$ & Sig & $\begin{array}{c}\text { Change in R } \\
\text { Square }\end{array}$ \\
\hline COMC $\longrightarrow$ NPDC & 0.232 & 0.481 & 5.434 & 0.000 & \\
\hline COMC $\longrightarrow$ FP & 0.285 & 0.534 & 6.246 & 0.000 & \\
\hline NPDC $\longrightarrow$ FP & 0.337 & 0.581 & 7.061 & 0.000 & \\
\hline COMC $\longrightarrow$ NPDC $\longrightarrow$ FP & 0.337 & 0.422 & 4.784 & 0.000 & 0.337 \\
& 0.421 & 0.331 & 3.754 & & 0.084 \\
\hline COMC $\rightarrow$ NPDC $\rightarrow$ MT $\rightarrow$ FP & 0.455 & 0.278 & 3.132 & 0.002 & \\
& & 0.371 & 4.203 & 0.000 & \\
\hline
\end{tabular}

Note: independent variables COMC, NPDC, MT and dependent variable FP) Table 8: Regression analysis (model summary).

\section{Moderation analysis}

To test for explanatory power of four processes, COMC, NPDC, MT, FP Regression approach was used [44-48]. R square=0.445 which shows significant relationship with Firm performance. Significance level $p=0.000$. Value of $t=3.13$. These results show that New product development capabilities mediates and Market Turbulence moderates the relationship between Firm's marketing capabilities to firm performance.

\section{Mediating analysis}

Mediating regression analysis was done to see the mediating effect of New product development capabilities between Customer oriented marketing capabilities and firm performance. $\mathrm{R}$ square $=0.337$ and Change in $\mathrm{R}$ square $=0.084$. $\mathrm{p}=0.000$ and value of $\mathrm{t}=4.784$.

Additionally following synergies were observed:

$$
\begin{array}{ll}
- & \mathrm{COMC}^{*} \mathrm{NPDC}: \text { Positive } \\
- & \mathrm{NPDC}{ }^{*} \mathrm{FP}: \text { Positive } \\
- & \mathrm{COMC}^{*} \mathrm{FP}: \text { Positive } \\
- & \mathrm{COMC}^{*} \mathrm{NPDC}{ }^{\star} \mathrm{FP}: \text { Mediating } \\
- & \mathrm{NPDC}^{\star} \mathrm{MT}{ }^{\star} \mathrm{FP}: \text { Positive }
\end{array}
$$

\section{Discussion}

This problem leads to the following questions:

1) How can the marketing department make its position strong in the new product development process and drive innovation performance; and

2) What role is played by the marketing department's position in influencing innovation outcomes and firm performance? With this idea in mind, the aim of this study was to identify relevant marketing capabilities that positively contribute to firm innovation performance and help strengthen the marketing department's influence on NPD. To ensure generalizable results, the analyses are based on a substantial sample of 100 respondents in B2C firms operating in a variety of industries (goods and services).

Marketing as a distinct function is important for driving innovation success. In particular, this study shows that in contrast to the commonly held view, not everyone in a firm can do marketing, and therefore, the marketing department should have a higher status in NPD.

\section{Conclusion}

The purpose of this study was to test a conceptual framework that broadens the role of customer oriented marketing capabilities in driving performance. My findings relate three different processes of firm and this had been done for the very first time. And it provides new insights. No previous studies have related these processes and provided clarity with respects to what these inputs should be and how they are likely to impact process performances and firms value. My study addresses these gaps and examines their implications and practice for marketing functions.

\section{Limitations for Future Research}

The sample of this study only consists of 100 respondents and few industries; still, the number of respondents is satisfying in relation to the statistical methods used. Besides, the other respondents of the total 
Citation: Harram A, Fozia M (2015) Customer Oriented Marketing Capabilities and Firm Performance Mediated by New Product Development Capabilities and Moderated by Environmental Turbulence. Int J Econ Manag Sci 4: 282. doi:10.4172/21626359.1000282

Page 7 of 8

sample are used to validate the results presented [49-53]. Nevertheless, if the number of respondents and number of industries had been higher, a more comprehensive analysis could have been carried out. That is an analysis that simultaneously takes into consideration all levels and all variables impacting Firm's performance. Firms performance, market turbulence and new product development capabilities often undergo changes from time to time.

- $\quad$ Even with the changing trends, many organizations in Pakistan still have no proper marketing departments.

- The sample used for the study was a rather limited one and was not able to conclude the impact of Customer oriented marketing capabilities on firms overall performance.

Along with this, all of the items included in the survey were measured using a five-point Likert-type scale. Thus, measuring all construct using one type of scale might create a mono-method bias, which can decrease the validity of the study. Another possible limitation is that sample was obtained from a survey of majority industries which include very few managers from relevant departments; therefore, results can be biased. Consequently, if the sample is increased and collected from different groups of people of different industries, then results might be generalized more vigorously.

\section{Managerial implications}

The common view in many companies is that marketing is not an important function, and therefore, everyone can do marketing. Due to which, the status of the marketing department is in a route of decline, which is especially observable within the new product development process. This development is surprising since it seems that top innovators strongly involve the marketing department in the new product development process. Therefore, strengthening the position of the marketing department with respect to new product development should be a priority to improve innovation performance. Managers should make marketing departments in their firms to improve firm performance and improve customer oriented marketing capabilities. Managers need to incorporate into their marketing decision making process the connections among different marketing constructs marketing resources, marketing intangibles, consumer response, financial performance in different periods of time. As I have come to know through my research methodology, these constructs are connected to each other through a network of processes. This study demonstrates that the traditional connection, in which marketing resources are linked to sales, is not enough to improve the bottom line of companies. Also, managers simply using marketing intangibles customer satisfaction, brand equity alone is not sufficient to grow the bottom line of their organizations either. Managers need to know how to incorporate the dynamics and network processes of marketing constructs to make their managerial practice really impactful.

\section{Practical implications}

This research is contributing towards the industrial sector of Pakistan with specific regard to attracting and retaining customers through COMC approach. This study can be extended towards the utilization of customer feedback in orienting their marketing activities. Through adoption of COMC approach, companies can garner more customer benefits and can make their customers feel concerned. This will ultimately enhance a firm's market worth.

\section{References}

1. Bolton RN (1998) A dynamic model of the duration of the customer's relationship with a continuous service provider: role of satisfaction. Marketing Science 17: $45-65$

2. Branson R (1998) Making brand extensions work. Sales and Marketing Management 150: 84.

3. Verhoef PC (2001) Analyzing customer relationships: Linking relationa constructs and marketing instruments to customer behavior. Doctora Dissertation, Tilburg Institute, Rotterdam.

4. Prahalad CK (1991) Corporate Imagination and Expeditionary Marketing Harvard Business Review 69: 81-92.

5. Vorhies DW, Orr LM, Bush VD (2011) Improving customer-focused marketing capabilities and firm financial via marketing exploration and exploitation. Journa of the Academy of Marketing Science 39: 736-756.

6. Ramaswami S, Srivastava R, Bhargava M (2009) Market-based capabilities and financial performance of firms: insights into marketing's contribution to firm value. Journal of the Academy Marketing Science 37: 97-116.

7. Peteraf M, Barney J (2003) Unraveling the Resource-Based Tangle. Managerial and Decision Economics 24: 309-323.

8. Helfat CE, Peteraf MA (2003) The Dynamic Resource-Based View: Capability Lifecycles Dynamic Capabilities. Strategic Management Journal 24: 997-1010.

9. Grinyer, Peter H (1988) Strategic Management Journal 9: 297.

10. Kohli AK, Bernard JJ (1990) Market Orientation: The Construct, Research Propositions, and Managerial Implications. Journal of Marketing 54: 1-18.

11. Dess GG, Richard BRJr (2006) Measuring Organizational Performance in the Absence of Objective Measures: The Case of the Privately-held Firm and Business Performance. Strategic Management Journal 5: 265-273.

12. Burnham AJ, Frels KJ, Mahajan V (2003) Consumer switching costs: a typology, antecendents, and consequences. Journal of the Academy of Marketing Science 31: 109-126.

13. Vorhies DW, Morgan NA (2005) Benchmarking marketing capabilities for sustainable competitive advantage. Journal of Marketing 69: 80-94.

14. Morgan NA (2003) Experiential and informational knowledge, architectural marketing capabilities, and the adaptive performance of export ventures: A cross-national study. Decision Sciences 34: 287-321.

15. Duboff RS (2008) Share the Dialogue-Even the best innovations experience communication failures. Marketing Management 17: 26.

16. Morgan N (2012) Marketing and business performance. Journal of the Acad. Marketing Science 40: 102-119.

17. Jayachandran S, Krasnikov, Alexander (2008) The relative impact of marketing, research-and-development, and operations capabilities on firm performance. Journal of Marketing 72: 1-11.

18. Morgan NA, Constantine SK, Douglas WV (2012) Export marketing strategy implementation, export marketing capabilities, and export venture performance. Journal of the Academy of Marketing Science 40: 271-289.

19. Day GS (1994) The capabilities of market-driven organizations. Journal of Marketing 58: 37-52.

20. Grover R, Madhavan, Ravindranath (1998) From embedded knowledge to embodied knowledge: new product development as knowledge management. The Journal of marketing 62: 1-12.

21. Moorman C, Slotegraaf $R$ (1999) The contingency value of complementary capabilities in product development. Journal of Marketing Research 36: 239 257

22. Song M, Droge C, Hanvanich S, Calantone R (2005) Marketing and technological resource complementarity: An analysis of their interaction effect in two environmental contexts. Strategic Management Journal 26: 259-276.

23. Hunt SD, Robert MM (1996) The resource-advantage theory of competition: dynamics, path dependencies, and evolutionary dimensions. The Journal of marketing 60: 107-114.

24. Oktemgil M, Gordon G (1997) Consequences of high and low adaptive capability in UK companies. European Journal of Marketing 31: 445- 466.

25. Argyres N (1996) Evidence on the role of firm capabilities in vertical integration decisions. Strategic Management Journal 17: 129-150. 
Citation: Harram A, Fozia M (2015) Customer Oriented Marketing Capabilities and Firm Performance Mediated by New Product Development Capabilities and Moderated by Environmental Turbulence. Int J Econ Manag Sci 4: 282. doi:10.4172/21626359.1000282

26. Slater SF, John CN (1998) Research notes and communications customerled and market-oriented: Let's not confuse the two. Strategic Management Journal 19: 1001-1006.

27. Dawar N, Philip P (1994) Marketing universals: Consumers' use of brand name, price, physical appearance, and retailer reputation as signals of product quality. The Journal of Marketing 58: 81-95.

28. Irvin RA, Michaels EG (1989) Core skills: Doing the right things right. McKinsey Quarterly pp: 4-19.

29. Marn VM, Rosiello R (1992) Managing price, gaining profit. Harvard Business Review pp: 84-94.

30. Bucklin A, Thomas DK (1996) Source regions for recruitment of Calanus finmarchicus to Georges Bank: evidence from molecular population genetic analysis of mtDNA. Deep Sea Research Part II: Topical Studies in Oceanography 43: 1665-1681.

31. Weitz BA, Sandy DJ (1995) Relationship marketing and distribution channels. Journal of the academy of Marketing Science 23: 305-320.

32. Anderson JC, James AN (1990) A model of distributor firm and manufacturer firm working partnerships. Journal of Marketing 54: 42-58

33. Challagalla GN, Tasadduq AS (1996) Dimensions and types of supervisory control: Effects on salesperson performance and satisfaction. The Journal of Marketing 60: 89-105.

34. Aaker DA (1991) Managing Brand Equity. The Free Press, New York, NY.

35. Aaker DA, Vineet K, George SD (2001). Marketing research (2ndedn.) John Wiley and Sons.

36. Boulding W (2005) A customer relationship management roadmap: What is known, potential pitfalls, and where to go. Journal of Marketing 69: 155-166.

37. Li D, Sethi IK, Dimitrova N, McGee T (2001) Classification of general audio data for content-based retrieval. Pattern recognition letters 22: 533-544.

38. Anderson E, Barton W (1992) The use of pledges to build and sustain commitment in distribution channels. Journal of marketing research 29: 18-34.

39. Sekaran, Uma (2006) Research methods for business: A skill building approach. John Wiley \& Sons.

40. Narver JC, Stanley FS (1990) The Effect of a Market Orientation on Business Profitability. Journal of Marketing 54: 20-35.

41. Narver J, Slater SF, Lachlan DL (2004) Responsive and Proactive Market
Orientation and New-Product Success. Journal of Product Innovation Management 21: 334-347.

42. Bendoly E (2011) Complementary Drivers of New Product Development Performance: Cross-Functional Coordination, Information System Capability and Intelligence Quality. Journal of Production and Operations Management Society 21: 653-667.

43. Kumar K, Subramanian R, Strandholm K (2011) Market Orientation And Performance: Does Organizational Strategy Matter. Journal of Applied Business Research 18: 37-49.

44. Bollag G, Clapp DW, Shih S, Adler F, Zhang YY, et al., (1996) Loss of NF1 results in activation of the Ras signaling pathway and leads to aberrant growth in haematopoietic cells. Nature genetics 12: 144-148.

45. Drechsler W, Leeflang PSH, Natter M (2013) Improving Marketing's Contribution to New Product Development. Journal of Product Innovation Management 30 298-315.

46. Eisen MB (1998) Cluster analysis and display of genome-wide expression patterns. Proceedings of the National Academy of Sciences 9: 14863-14868.

47. Jensen PS (1997) Evolution and revolution in child psychiatry: ADHD as a disorder of adaptation. Journal of the American Academy of Child \& Adolescent Psychiatry 36: 1672-1681.

48. Yoon SJ, Sung SH (2005) Market-oriented culture and marketing strategy on firm performance, Journal of Strategic Marketing 16: 1-20.

49. Olimpia CR (2014) Customer orientation, innovation competencies, and firm performance: A proposed conceptual model - Social and Behavioral Sciences 148: 16-23.

50. Ruiz FA, Donthu N, Prior D, Josep R (2013) The financial contribution of customer-oriented marketing capability. Journal of Academy of Marketing Science 42: 380-399.

51. Talpau D, Boscor (2011) Customer-Oriented Marketing - A Strategy that guarantee success: Starbucks and Mcdonald's. Bulletin of the Transilvania University of Braşov 4: 52- 58.

52. Weerawardena $\mathrm{J}(2003)$ The role of marketing capability in innovation-based competitive strategy. Journal of strategic marketing 11: 15-35.

53. Yong T, Okten D (2011) Exploring a dynamic framework of innovative capability: a theoretical integration of technological and marketing capabilities. Technology Analysis and Strategic Management 23: 1001-1013. 